\title{
Associations between obesity, weight change and decreased renal function in Korean type 2 diabetic patients: a longitudinal follow-up study
}

Bo-Yeon Kim, Dug-Hyun Choi, Chan-Hee Jung, Ji-Oh Mok and Chul-Hee Kim*

\begin{abstract}
Background: We aimed to examine the associations between the risk of decreased renal function, obesity, and weight changes in Korean type 2 diabetic patients with normal renal function.

Methods: Type 2 diabetic patients $(n=1060)$ who visited the diabetic clinic at Soonchunhyang University Bucheon Hospital between 2001 and 2007 with follow up surveys completed in 2016 to 2017 were recruited into the study. Decreased renal function was defined as an estimated glomerular filtration rate $<60 \mathrm{~mL} / \mathrm{min} / 1.73 \mathrm{~m}^{2}$. Weight change was calculated between baseline and each follow-up survey. Multivariate analysis was used to evaluate the longitudinal association of baseline obesity and weight changes with the risk of decreased renal function.

Results: This study revealed that baseline obesity was associated with the risk of decreased renal function after adjusting for clinical variables in type 2 diabetic patients (odds ratio [OR] 1.40; 95\% confidence intervals [CI] 1.082.04; $p=0.025$ ). Follow-up (mean $=12$ years) revealed that weight gain $>10 \%$ was associated with the risk of decreased renal function after adjusting for clinical variables in type 2 diabetic patients with normal renal function at baseline (OR 1.43; $\mathrm{Cl} 1.11-2.00 ; p=0.016)$. Weight loss was not associated with the risk of decreased renal function in type 2 diabetic patients with normal renal function at baseline.

Conclusions: Baseline obesity was associated with the increased risk of decreased renal function in Korean type 2 diabetic patients with normal renal function. Weight gain $>10 \%$ independently predicted the risk of decreased renal function. Large prospective studies are needed to clarify causal associations between obesity, weight change, and decreased renal function in patients with type 2 diabetes.
\end{abstract}

Keywords: Obesity, Body weight changes, Diabetes mellitus, Type 2, Decreased renal function

\footnotetext{
* Correspondence: chkimem@schmc.ac.kr

Division of Endocrinology and Metabolism, Department of Internal Medicine, Soonchunhyang University Bucheon Hospital, Soonchunhyang University College of Medicine, 170 Jomaru-ro, Wonmi-gu, Bucheon 14584, Republic of Korea
}

C The Author(s). 2021 Open Access This article is licensed under a Creative Commons Attribution 4.0 International License, which permits use, sharing, adaptation, distribution and reproduction in any medium or format, as long as you give appropriate credit to the original author(s) and the source, provide a link to the Creative Commons licence, and indicate if changes were made. The images or other third party material in this article are included in the article's Creative Commons licence, unless indicated otherwise in a credit line to the material. If material is not included in the article's Creative Commons licence and your intended use is not permitted by statutory regulation or exceeds the permitted use, you will need to obtain permission directly from the copyright holder. To view a copy of this licence, visit http://creativecommons.org/licenses/by/4.0/. The Creative Commons Public Domain Dedication waiver (http://creativecommons.org/publicdomain/zero/1.0/) applies to the data made available in this article, unless otherwise stated in a credit line to the data. 


\section{Background}

Obesity is a major risk factor for type 2 diabetes, hypertension, and other comorbidities [1]. In Korea, the prevalence of diabetes has increased due to an aging population [2]. In 2016, diabetes was the most common cause of renal replacement therapy in Korea [3]. The prevalence of chronic kidney disease (CKD) among adults was reported as $8.2 \%$ in a nationwide representative sample of the Korean population [4]. Clinical factors such as aging, diabetes, and hypertension may be associated with the increasing prevalence of CKD $[4,5]$. Recently, a link between obesity and decreased renal function has been identified. Obesity has been reported to promote renal dysfunction by several mechanisms including alterations in renal hemodynamics and inflammation $[6,7]$. A meta-analysis suggested that obesity has a U-shaped association with the risk of kidney disease in patients with hypertension [8]. Conversely, some studies reported that high body mass index (BMI) is protective for renal function deterioration in type 2 diabetes and CKD $[9,10]$.

Since the prevalence of obesity in diabetic patients is increasing [11], and diabetes is the main cause of CKD [5], it is important to understand how changes in body weight and waist circumference affect the progression of CKD in patients with diabetes and chronic disease. To our knowledge, few studies have examined the effects of weight change on the risk of developing CKD in Asian patients with type 2 diabetes. In present study, we investigated the associations between the risk of decreased renal function, obesity, and weight changes in Korean type 2 diabetic patients with normal renal function.

\section{Methods}

\section{Subjects}

Korean patients with type 2 diabetes $(n=1060)$ who visited the diabetes clinic at Soonchunhynag University $\mathrm{Bu}$ cheon Hospital between 2001 and 2007 with follow-up surveys completed in 2015 to 2017 were recruited into the study. Individuals diagnosed with type 1 diabetes, renal insufficiency (estimated glomerular filtration rate [eGFR] $<60 \mathrm{~mL} / \mathrm{min} / 1.73 \mathrm{~m}^{2}$ ), chronic liver disease, chronic infection, or malignancy were excluded. Decreased renal function was defined as an eGFR $<60 \mathrm{~mL} /$ $\min / 1.73 \mathrm{~m}^{2}$. Based upon the Modification of Diet in Renal Disease formula, eGFR was calculated as follows: eGFR $(\mathrm{mL} / \mathrm{min} / 1.73 \mathrm{~m} 2)=186 \times$ serum creatinine $(\mathrm{mg} /$ dL) $-1.154 \times($ age $)-0.203 \times(0.742$ if female $)$.

BMI was categorized as normal $\left(<23 \mathrm{~kg} / \mathrm{m}^{2}\right)$, overweight $\left(23-24.9 \mathrm{~kg} / \mathrm{m}^{2}\right)$, or obese $\left(\geq 25 \mathrm{~kg} / \mathrm{m}^{2}\right)$ in accordance with WHO guidelines for the Asia-Pacific region [12] and 2018 Korean Society for the Study of Obesity Guideline [13]. Weight change was calculated between baseline measurements and that at the time of each follow-up survey. Relative risk of decreased renal function and 95\% confidence intervals (CI) were estimated. To estimate the risk of decreased renal function, associations were examined in patients who were followed up regularly $(n=861)$. The study protocol conformed to the ethical guidelines of the 1975 Declaration of Helsinki and was approved by the Institutional Review Board (IRB) of Soonchunhyang University Bucheon Hospital (IRB no. 2020-03-015).

\section{Measurements}

At the initial visit, fasting glucose, glycated hemoglobin (HbA1c), fasting total serum cholesterol, triglyceride, high-density lipoprotein cholesterol, low-density lipoprotein cholesterol, aspartate aminotransaminase, alanine aminotransferase (ALT), and creatinine were measured. Serum creatinine was assayed by calorimetry using Beckman Coulter AU analyzer (Beckman Coulter Inc., Brea, CA, USA) following the Jaffe method and it was IDMS standardized [14]. HbA1c was measured using ionexchange high-performance liquid chromatography (BioRad, Hercules, CA, USA) (4.0-6.0\%). Albuminuria was measured using a radioimmunoassay (Immunotech, Marseille, France) using spot urine or time-collected urine. Microalbuminuria was defined as an albumin excretion rate of $20-200 \mu \mathrm{g} / \mathrm{min}$, an albumin/creatinine ratio in spot urine of $30-300 \mathrm{mg} / \mathrm{g}$, or a 24 -h urine protein of $30-300 \mathrm{mg} /$ day. Overt albuminuria was defined as an albumin excretion rate $>200 \mu \mathrm{g} / \mathrm{min}$, an albumin/creatinine ratio in spot urine of $>300 \mathrm{mg} / \mathrm{g}$, or a 24-h urine protein of $>300 \mathrm{mg} /$ day. All laboratory tests were measured in one laboratory.

\section{Statistical analysis}

Statistical analyses were performed using SPSS Statistics version 26.0 (IBM Corp., Armonk, NY, USA). Values are represented as mean \pm standard deviation for variables that were normally distributed, median (interquartile range) for variables that were not normally distributed, or the number of participants (percentages). $P$-values less than 0.05 were considered to be statistically significant. A chi-square test was performed to compare categorical variables. One-way analysis of variance was performed to evaluate the differences in means among BMI categories. Multivariate logistic regression was performed to identify the longitudinal associations of baseline obesity and weight changes with the risk of decreased renal function.

\section{Results}

The baseline characteristics of study participants are presented in Table 1 . Subjects $(n=1060)$ were analyzed and divided into three groups according to BMI categories as described in Materials and Methods. The 
Table 1 Baseline characteristics of 1060 participants with type 2 diabetes according to the body mass index categories

\begin{tabular}{|c|c|c|c|c|}
\hline Characteristic & $\begin{array}{l}\mathrm{BMI}<23 \\
(n=320,30.2 \%)\end{array}$ & $\begin{array}{l}23 \leq \mathrm{BMI}<25 \\
(n=255,24.1 \%)\end{array}$ & $\begin{array}{l}\mathrm{BMI} \geq 25 \\
(n=485,45.8 \%)\end{array}$ & $p$ \\
\hline Age (year) & $56.3 \pm 8.4$ & $56.7 \pm 8.5$ & $54.1 \pm 8.7$ & 0.002 \\
\hline $\operatorname{Sex}(\%)$ & & & & 0.003 \\
\hline Men & 44.6 & 53.0 & 42.3 & \\
\hline Women & 55.4 & 47.0 & 57.7 & \\
\hline BMI $\left(\mathrm{kg} / \mathrm{m}^{2}\right)$ & $21.5 \pm 1.3$ & $24.1 \pm 1.3$ & $29.4 \pm 2.7$ & $<0.001$ \\
\hline Duration of type 2 diabetes (year) & $6.5 \pm 5.3$ & $5.0 \pm 4.5$ & $5.5 \pm 5.4$ & NS \\
\hline HbA1c (\%) & $7.4 \pm 1.5$ & $7.3 \pm 1.7$ & $8.3 \pm 1.7$ & 0.005 \\
\hline Fasting glucose (mg/dL) & $133.6 \pm 33.1$ & $175.1 \pm 57.3$ & $180.3 \pm 47.3$ & $<0.001$ \\
\hline AST (U/L) & $35.6 \pm 9.6$ & $36.3 \pm 11.2$ & $36.8 \pm 10.3$ & NS \\
\hline $\operatorname{ALT}(U / L)$ & $39.6 \pm 10.4$ & $41.9 \pm 14.7$ & $45.8 \pm 1.7$ & 0.002 \\
\hline Total-cholesterol (mg/dL) & $160.9 \pm 32.5$ & $186.2 \pm 43.8$ & $192.0 \pm 48.7$ & 0.002 \\
\hline LDL-cholesterol (mg/dL) & $93.3 \pm 27.4$ & $102.3 \pm 40.7$ & $106 \pm 50.7$ & 0.001 \\
\hline HDL-cholesterol (mg/dL) & $43.3 \pm 10.6$ & $46.5 \pm 16.1$ & $42.5 \pm 16.1$ & NS \\
\hline Triglycerides (mg/dL) & $155.7 \pm 67.6$ & $177.9 \pm 131.3$ & $197.9 \pm 141.3$ & 0.001 \\
\hline Hypertension (\%) & 61.5 & 68.0 & 71.0 & 0.040 \\
\hline eGFR $\left(\mathrm{mL} / \mathrm{min} / 1.73 \mathrm{~m}^{2}\right)^{\mathrm{a}}$ & $75.2 \pm 11.1$ & $74.6 \pm 13.9$ & $70.5 \pm 13.0$ & 0.002 \\
\hline Albuminuria (\%) & 31.6 & 29.0 & 30.5 & NS \\
\hline
\end{tabular}

The data is presented as mean \pm standard deviation

$B M I$ body mass index, $H b A 1 c$ glycated hemoglobin, $A S T$ aspartate aminotransaminase, $A L T$ alanine aminotransferase, $L D L$ low-density lipoprotein, $H D L$ high-density lipoprotein, eGFR estimated glomerular filtration rate, NS not significant

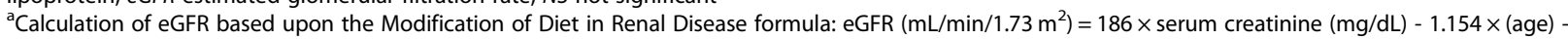

$0.203 \times(0.742$ if female $) \times(1.21$ if black $)$

prevalence of obesity (BMI $\geq 25 \mathrm{~kg} / \mathrm{m}^{2}$ ) was $45.8 \%$ in subjects with type 2 diabetes. Obese patients had higher HbA1c, higher ALT, and a less favorable lipid profile, whereas no differences were found between the three BMI groups in eGFR or the prevalence of albuminuria (Table 1).

Baseline obesity was associated with higher odds ratios (OR) for decreased renal function after adjusting for clinical factors such as age, sex, duration of type 2 diabetes, HbA1c, total cholesterol, triglycerides, and hypertension at baseline (OR 1.40; CI 1.08-2.04; $p=0.025$ ) (Table 2, Fig. 1). The overweight group did not have a higher risk of decreased renal function (OR 1.20; CI $0.96-1.63 ; p=0.102)$ (Table 2).

In type 2 diabetic patients with normal renal function, weight gain $>10 \%$ was associated with the risk of decreased renal function during follow-up (mean $=12$ years) after adjusting for clinical variables at baseline (OR 1.43; CI 1.11-2.00; $p=0.016$ ). However, weight gain of $5-10 \%$ and weight loss of $5-10 \%$ were not associated with the risk of decreased renal function in type 2 diabetic patients with normal renal function at baseline. Moreover, weight loss of any magnitude was not associated with the risk of decreased renal function in type 2

Table 2 Longitudinal association between baseline obesity and risk of decreased renal function (estimated glomerular filtration rate $\left.<60 \mathrm{~mL} / \mathrm{min} / 1.73 \mathrm{~m}^{2}\right)(n=1060)$

\begin{tabular}{|c|c|c|c|c|c|c|}
\hline & \multicolumn{2}{|l|}{ Age-adjusted } & \multicolumn{2}{|l|}{ Model $1^{a}$} & \multicolumn{2}{|l|}{ Model $2^{b}$} \\
\hline & RR (95\% Cl) & $p$ & RR (95\% Cl) & $p$ & RR (95\% Cl) & $p$ \\
\hline \multicolumn{7}{|l|}{ BMI $\left(\mathrm{kg} / \mathrm{m}^{2}\right)$} \\
\hline $\mathrm{BMI}<23$ & 1 (reference) & & 1 (reference) & & 1 (reference) & \\
\hline $23 \leq \mathrm{BMI}<25$ & $1.11(0.93-1.59)$ & 0.190 & $1.24(0.96-1.65)$ & 0.090 & $1.20(0.96-1.63)$ & 0.102 \\
\hline $\mathrm{BMI} \geq 25$ & $1.36(1.07-2.00)$ & 0.020 & $1.44(1.12-2.12)$ & 0.017 & $1.40(1.08-2.04)$ & 0.025 \\
\hline
\end{tabular}

$B M I$ body mass index, $R R$ relative risk, $\mathrm{Cl}$ confidence interval

${ }^{a}$ Model 1: adjusted for age, sex, and duration of type 2 diabetes

${ }^{\mathrm{b}}$ Model 2: adjusted for Model $1+$ glycated hemoglobin, total cholesterol, triglycerides, and hypertension (high blood pressure or anti-hypertensive medication use) 


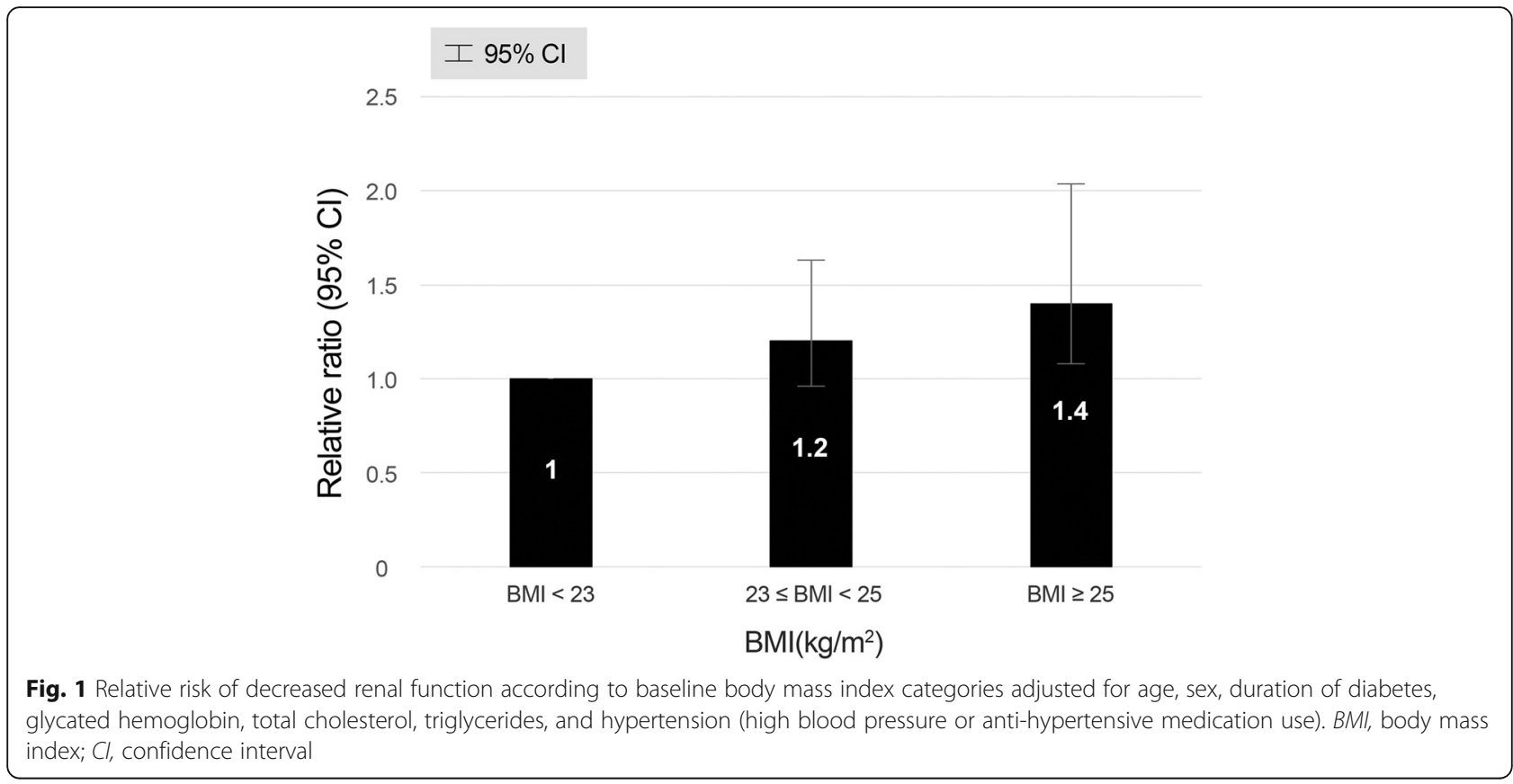

diabetic patients with normal renal function (OR 0.98; CI 0.58-1.46; $p=0.719$ ) (Table 3, Fig. 2).

\section{Discussion}

Our study demonstrates that baseline obesity is associated with the risk of decreased renal function and that weight gain $>10 \%$ is an independent predictor of decreased renal function in Korean type 2 diabetic patients with normal renal function. Overweight patients $(23 \leq$ $\mathrm{BMI}<25)$ did not have a higher risk of decreased renal function. Weight loss and weight gain $<10 \%$ were not associated with the risk of decreased renal function in type 2 diabetic patients with normal renal function at baseline.

In several population-based studies, higher BMI was associated with the presence of CKD $[15,16]$, decreased eGFR [17-19], and incidental end-stage renal disease
[20, 21]. Our findings in Korean patients with type 2 diabetes are consistent with the results of previous studies. It is thought that because type 2 diabetes is a major cause of CKD and those with type 2 diabetes represent a population with different health characteristics than healthy subjects, the specific study of CKD in diabetic patients is of importance. Higher BMI was reported as an independent predictor of major renal events in patients with type 2 diabetes [22]. In Asian diabetics, obesity was shown to be associated with increased albuminuria and diabetic kidney disease [23]. However, some studies of Asian diabetic patients have demonstrated a negative correlation between obesity and new onset of CKD (eGFR $<60 \mathrm{~mL} / \mathrm{min} / 1.73 \mathrm{~m}^{2}$ ) [9, 24].. According to the Hong Kong Diabetes Registry, CKD is positively correlated with central obesity and negatively correlated with BMI [9]. Sarcopenia due to malnutrition

Table 3 Longitudinal association of body weight changes and risk of decreased renal function (estimated glomerular filtration rate $\left.<60 \mathrm{~mL} / \mathrm{min} / 1.73 \mathrm{~m}^{2}\right)(n=861)$

\begin{tabular}{|c|c|c|c|c|c|c|}
\hline & \multicolumn{2}{|l|}{ Age-adjusted } & \multicolumn{2}{|l|}{ Model $1^{\mathrm{a}}$} & \multicolumn{2}{|l|}{ Model $2^{b}$} \\
\hline & RR (95\% Cl) & $p$ & RR $(95 \% \mathrm{Cl})$ & $p$ & RR (95\% Cl) & $p$ \\
\hline \multicolumn{7}{|l|}{ Body weight change (\%) } \\
\hline Weight gain > 10 & $1.50(1.12-2.01)$ & 0.003 & $1.44(1.11-2.00)$ & 0.005 & $1.43(1.11-2.00)$ & 0.016 \\
\hline $5<$ weight gain $\leq 10$ & $1.03(0.70-1.29)$ & 0.710 & $1.03(0.70-1.29)$ & 0.740 & $1.04(0.70-1.29)$ & 0.634 \\
\hline Stable \pm 5 & 1 (reference) & & 1 (reference) & & 1 (reference) & \\
\hline $5<$ weight loss $\leq 10$ & $1.07(0.77-1.40)$ & 0.450 & $1.05(0.77-1.40)$ & 0.457 & $1.07(0.77-1.40)$ & 0.519 \\
\hline Weight loss > 10 & $0.98(0.58-1.46)$ & 0.602 & $0.99(0.58-1.48)$ & 0.702 & $0.98(0.58-1.46)$ & 0.719 \\
\hline
\end{tabular}

$R R$ relative risk, $\mathrm{Cl}$ confidence interval

${ }^{a}$ Model 1: adjusted for age, sex, and duration of type 2 diabetes

${ }^{\mathrm{b}}$ Model 2: adjusted for Model $1+$ glycated hemoglobin, total cholesterol, triglycerides, and hypertension (high blood pressure or anti-hypertensive medication use) 


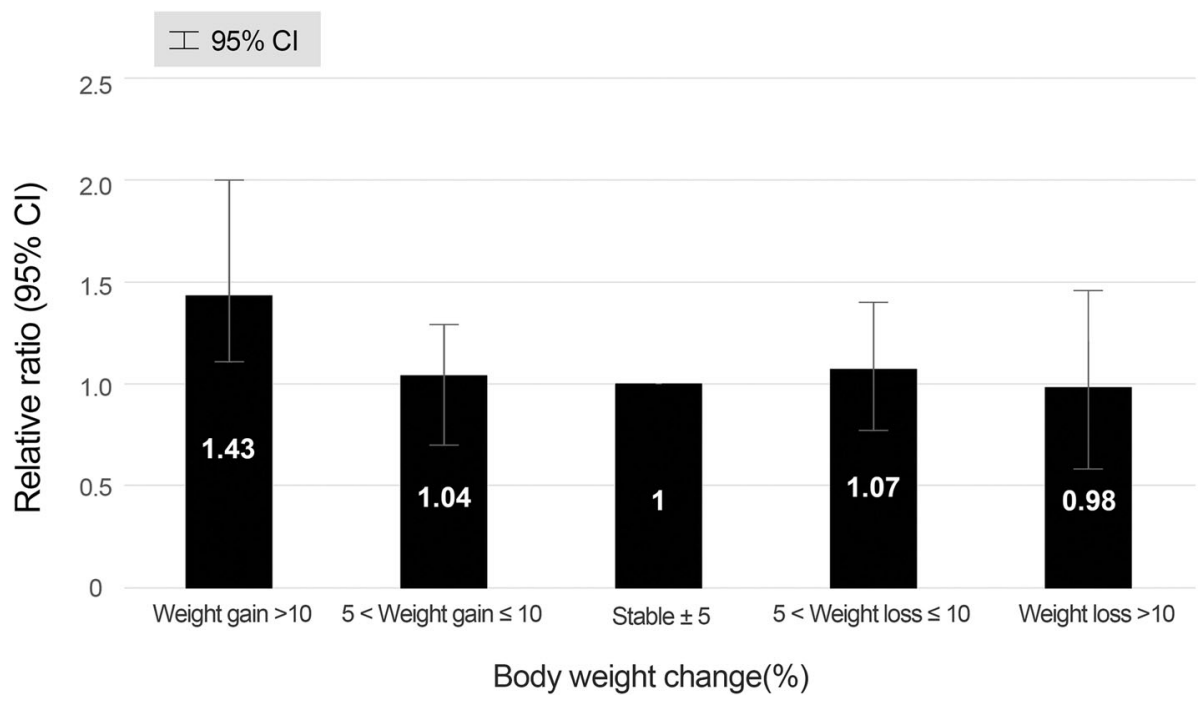

Fig. 2 Relative risk of decreased renal function according to body weight changes categories adjusted for age, sex, duration of diabetes, glycated hemoglobin, total cholesterol, triglycerides, and hypertension (high blood pressure or anti-hypertensive medication use). Cl, confidence interval

is common in CKD patients, resulting in a decrease in BMI with subsequent effects on clinical outcomes. A previous study described this observation as a reverse causality [25]. BMI may not be a reliable marker of outcome in CKD patients [26]. Extensive research is needed to clarify these controversies.

Patients with type 2 diabetes have several comorbidities [11]. It is important to take into consideration that weight gain can affect hypertension, dyslipidemia, and hyperglycemia. The understanding of the effects of weight gain on the development of CKD is important, which was the objective of the present study encompassing these clinical factors.

In this study, baseline body weight was associated with a higher risk of incidental CKD. Several recent studies demonstrated the association between obesity and increased risk of CKD. However, few studies have investigated whether weight gain increases the risk for CKD. In a Japanese study, the relative risk for incident CKD was higher in the normal weight participants with a weight gain of $>10 \mathrm{~kg}$ than those without weight gain [27].

In another study in Europeans, waist circumference (WC) changes were not associated with the incident CKD in women, whereas a severe increase in WC was associated with increased risk of CKD [28]. The effect of obesity on CKD may be different between men and women.

Factors involved in the progression of CKD and mechanisms by which obesity may affect CKD are not fully clarified yet. However, several mechanisms have been proposed. Various metabolic diseases associated with obesity may lead to kidney damage. The association between metabolic syndrome and kidney disease is well known [29, 30]. Obesity has a direct effect on the kidneys. Adiposity leads to the dysfunction of adipocytokines, such as adiponectin [31], leptin [32], and resistin [33], which may affect the kidneys. Increased inflammation, oxidative stress [34], increased renin-angiotensinaldosterone system [35], and insulin resistance [36] are known as mechanisms of renal failure in obesity. Specific pathologic changes associated with obesity such as hyperfiltration-related glomerulopathy [37] and increased nephrolithiasis [38] may be important CKDrelated mechanisms. In a study of type 2 diabetes, an increase in IL-6 associated with weight gain was shown to be related to an increased risk of CKD [39].

In the present study, weight loss was not associated with decreased renal function. Similar to our findings, a decrease in WC was not related to a lower risk of CKD in another recent study [28]. In another study, intensive lifestyle intervention concentrating on weight loss could not decrease cardiovascular events in overweight or obese patients with type 2 diabetes but delayed the rate of progression [40]. In type 2 diabetic patients with various metabolic diseases, weight loss may hinder the progression of various metabolic diseases thereby preventing CKD and protecting the kidneys [40].

This study has several limitations. First, we focused on GFR in this study. Obesity is an important cause of proteinuria, such as obesity related nephropathy. Further study is needed to observe the association between obesity and proteinuria during the long-term follow-up. Second, the single-center design may introduce selection bias. However, the laboratory results of this study population are highly consistent with the broader Asian population. Despite these limitations, our study has the advantage of a long mean follow up of 12 years. 
In conclusion, obesity was associated with the increased risk of decreased renal function in Korean type 2 diabetic patients with normal renal function. Weight gain $>10 \%$ independently predicted decreased renal function. Large prospective studies are needed to clarify causal associations between obesity, weight change, and decreased renal function in patients with type 2 diabetes.

\section{Abbreviations}

ALT: Alanine aminotransferase; AST: Aspartate aminotransaminase; BMI: Body mass index; Cl: Confidence intervals; CKD: Chronic kidney disease; eGFR: Estimated glomerular filtration rate; HbA1c: Glycated hemoglobin; HDL: High-density lipoprotein; IRB: Institutional Review Board; LDL: Lowdensity lipoprotein; NS: Not significant; OR: Odds ratio; RR: Relative risk; T2DM: Type 2 diabetes mellitus; WC: Waist circumference

\section{Acknowledgements}

Not Applicable.

\section{Authors' contributions}

Conceptualization, BYK and CHK; Methodology, CHJ and JOM; Formal analysis, DHC; Writing-original draft preparation, BYK; Writing-review and editing; $\mathrm{DHC}, \mathrm{CHJ}$, and JOM; Supervision, CHK. All authors read and approved the final manuscript.

\section{Funding}

This work was partly supported by the Soonchunhyang University Research Fund.

\section{Availability of data and materials}

Restrictions apply to the availability of these data, which were used under license for the current study, and so are not publicly available. Administrative permissions from the IRB of the Soonchunhyang University Bucheon Hospital are required to access the raw data.

\section{Declarations}

\section{Ethics approval and consent to participate}

The study protocol was approved by the Institutional Review Board (IRB) of Soonchunhyang University Bucheon Hospital (IRB No. 2020-03-015). The requirement for informed consent was waived from the IRB because this study was performed by retrospective analysis of pre-existing clinical data. Administrative permissions were required to access the raw data, which were granted to the corresponding author (CHK) by the IRB of the Soonchunhyang University Bucheon Hospital.

\section{Consent for publication}

Not Applicable.

\section{Competing interests}

The authors declare that they have no competing interests.

Received: 18 May 2020 Accepted: 6 September 2021

Published online: 17 September 2021

\section{References}

1. Hall ME, do Carmo JM, da Silva AA, Juncos LA, Wang Z, Hall JE. Obesity, hypertension, and chronic kidney disease. Int J Nephrol Renovasc Dis. 2014; 7:75-88. https://doi.org/10.2147/IJNRD.S39739.

2. Ha KH, Kim DJ. Trends in the diabetes epidemic in Korea. Endocrinol Metab (Seoul). 2015;30(2):142-6. https://doi.org/10.3803/EnM.2015.30.2.142.

3. Shin HY, et al. Cause-of-death statistics in 2016 in the Republic of Korea. J Korean Med Assoc. 2018;61(9):573-84. https://doi.org/10.5124/jkma.2018.61. 9.573 .

4. Park Jl, Baek H, Jung HH. Prevalence of chronic kidney disease in Korea: the Korean National Health and nutritional examination survey 20112013. J Korean Med Sci. 2016;31(6):915-23. https://doi.org/10.3346/jkms.2 016.31.6.915.
5. Zhang L, Long J, Jiang W, Shi Y, He X, Zhou Z, et al. Trends in chronic kidney disease in China. N Engl J Med. 2016;375(9):905-6. https://doi.org/1 0.1056/NEJMc1602469

6. Tsuboi N, Utsunomiya Y, Hosoya T. Obesity-related glomerulopathy and the nephron complement. Nephrol Dial Transplant. 2013;28(Suppl 4):iv108-13.

7. Mallamaci F, Tripepi G. Obesity and CKD progression: hard facts on fat CKD patients. Nephrol Dial Transplant. 2013;28(Suppl 4):iv105-8.

8. Wang Y, Chen X, Song Y, Caballero B, Cheskin LJ. Association between obesity and kidney disease: a systematic review and meta-analysis. Kidney Int. 2008;73(1):19-33. https://doi.org/10.1038/sj.ki.5002586.

9. Luk AO, So WY, Ma RC, Kong AP, Ozaki R, Ng VS, et al. Metabolic syndrome predicts new onset of chronic kidney disease in 5,829 patients with type 2 diabetes: a 5-year prospective analysis of the Hong Kong diabetes registry. Diabetes Care. 2008;31(12):2357-61. https://doi.org/10.2337/dc08-0971.

10. Huang WH, Chen CY, Lin JL, Lin-Tan DT, Hsu CW, Yen TH. High body mass index reduces glomerular filtration rate decline in type $\|$ diabetes mellitus patients with stage 3 or 4 chronic kidney disease. Medicine (Baltimore). 2014;93(7):e41. https://doi.org/10.1097/MD.0000000000000041.

11. Kim BY, Won JC, Lee JH, Kim HS, Park JH, Ha KH, et al. Diabetes fact sheets in Korea, 2018: an appraisal of current status. Diabetes Metab J. 2019;43(4): 487-94. https://doi.org/10.4093/dmj.2019.0067.

12. Organization, W.H, The Asia-Pacific perspective: redefining obesity and its treatment. 2000

13. Seo MH, Lee WY, Kim SS, Kang JH, Kang JH, Kim KK, et al. 2018 Korean Society for the Study of obesity guideline for the Management of Obesity in Korea. J Obes Metab Syndr. 2019;28(1):40-5. https://doi.org/10.7570/ jomes.2019.28.1.40.

14. Myers $\mathrm{GL}$, et al. Recommendations for improving serum creatinine measurement: a report from the laboratory working Group of the National Kidney Disease Education Program. Clin Chem. 2006;52(1):5-18. https://doi. org/10.1373/clinchem.2005.0525144.

15. Pinto-Sietsma SJ, Navis G, Janssen WMT, de Zeeuw D, Gans ROB, de Jong PE. A central body fat distribution is related to renal function impairment, even in lean subjects. Am J Kidney Dis. 2003;41(4):733-41. https://doi.org/1 0.1016/S0272-6386(03)00020-9.

16. Ejerblad E, Fored CM, Lindblad P, Fryzek J, McLaughlin JK, Nyrén O. Obesity and risk for chronic renal failure. J Am Soc Nephrol. 2006;17(6):1695-702. https://doi.org/10.1681/ASN.2005060638.

17. Foster MC, Hwang SJ, Larson MG, Lichtman JH, Parikh NI, Vasan RS, et al. Overweight, obesity, and the development of stage 3 CKD: the Framingham heart study. Am J Kidney Dis. 2008;52(1):39-48. https://doi.org/10.1053/j.a jkd.2008.03.003.

18. Gelber RP, Kurth T, Kausz AT, Manson JAE, Buring JE, Levey AS, et al. Association between body mass index and CKD in apparently healthy men. Am J Kidney Dis. 2005;46(5):871-80. https://doi.org/10.1053/j.ajkd.2005.08.015.

19. Lu JL, Molnar MZ, Naseer A, Mikkelsen MK, Kalantar-Zadeh K, Kovesdy CP. Association of age and BMI with kidney function and mortality: a cohort study. Lancet Diabetes Endocrinol. 2015;3(9):704-14. https://doi.org/10.1016/ S2213-8587(15)00128-X.

20. Iseki K, Ikemiya Y, Kinjo K, Inoue T, Iseki C, Takishita S. Body mass index and the risk of development of end-stage renal disease in a screened cohort. Kidney Int. 2004;65(5):1870-6. https://doi.org/10.1111/j.1523-1 755.2004.00582.x.

21. Hsu CY, McCulloch CE, Iribarren C, Darbinian J, Go AS. Body mass index and risk for end-stage renal disease. Ann Intern Med. 2006;144(1):21-8. https:// doi.org/10.7326/0003-4819-144-1-200601030-00006.

22. Mohammedi K, Chalmers J, Herrington W, Li Q, Mancia G, Marre M, et al. Associations between body mass index and the risk of renal events in patients with type 2 diabetes. Nutr Diabetes. 2018;8(1):7. https://doi.org/10.1 038/s41387-017-0012-y.

23. Duan J, Wang C, Liu D, Qiao Y, Pan S, Jiang D, et al. Prevalence and risk factors of chronic kidney disease and diabetic kidney disease in Chinese rural residents: a cross-sectional survey. Sci Rep. 2019;9(1):10408. https://doi. org/10.1038/s41598-019-46857-7.

24. Zaman SB, Hossain N, Rahman M. Associations between body mass index and chronic kidney disease in type 2 diabetes mellitus patients: findings from the northeast of Thailand. Diabetes Metab J. 2018:42(4):330-7. https:// doi.org/10.4093/dmj.2017.0052.

25. Mafra D, Guebre-Egziabher F, Fouque D. Body mass index, muscle and fat in chronic kidney disease: questions about survival. Nephrol Dial Transplant. 2008;23(8):2461-6. https://doi.org/10.1093/ndt/gfn053. 
26. Janssen I, Katzmarzyk PT, Ross R. Waist circumference and not body mass index explains obesity-related health risk. Am J Clin Nutr. 2004;79(3):379-84. https://doi.org/10.1093/ajcn/79.3.379.

27. Michishita R, Matsuda T, Kawakami S, Tanaka S, Kiyonaga A, Tanaka H, et al. Long-term body weight gain after maturity is associated with the incidence of chronic kidney disease (CKD), independent of current body weight, in middle-aged and older men. J Epidemiol. 2019;29(6):213-9. https://doi.org/1 0.2188/jea.JE20170304.

28. Barzin M, Hosseinpanah F, Serahati S, Salehpour M, Nassiri AA, Azizi F. Changes in waist circumference and incidence of chronic kidney disease. Eur J Clin Investig. 2014;44(5):470-6. https://doi.org/10.1111/eci.12253.

29. Thomas G, Sehgal AR, Kashyap SR, Srinivas TR, Kirwan JP, Navaneethan SD. Metabolic syndrome and kidney disease: a systematic review and metaanalysis. Clin J Am Soc Nephrol. 2011;6(10):2364-73. https://doi.org/10.2215/ CJN.02180311.

30. Raikou VD, Gavriil S. Metabolic Syndrome and Chronic Renal Disease. Diseases. 2018;6. https://doi.org/10.3390/diseases6010012.

31. Sharma K. The link between obesity and albuminuria: adiponectin and podocyte dysfunction. Kidney Int. 2009;76(2):145-8. https://doi.org/10.1038/ ki.2009.137.

32. Wolf G, Ziyadeh FN. Leptin and renal fibrosis. Contrib Nephrol. 2006;151: 175-83. https://doi.org/10.1159/000095328.

33. Ellington AA, Malik AR, Klee GG, Turner ST, Rule AD, Mosley TH Jr, et al. Association of plasma resistin with glomerular filtration rate and albuminuria in hypertensive adults. Hypertension. 2007;50(4):708-14. https:// doi.org/10.1161/HYPERTENSIONAHA.107.095257.

34. Tang J, Yan H, Zhuang S. Inflammation and oxidative stress in obesityrelated glomerulopathy. Int J Nephrol. 2012;2012:608397.

35. Rüster $\mathrm{C}$, Wolf $\mathrm{G}$. The role of the renin-angiotensin-aldosterone system in obesity-related renal diseases. Semin Nephrol. 2013;33(1):44-53. https://doi. org/10.1016/j.semnephrol.2012.12.002.

36. Reaven GM. Banting lecture 1988. Role of insulin resistance in human disease. Diabetes. 1988:37(12):1595-607. https://doi.org/10.2337/diabetes.3 7.12.1595.

37. Tsuboi N, Utsunomiya Y, Kanzaki G, Koike K, Ikegami M, Kawamura T, et al. Low glomerular density with glomerulomegaly in obesity-related glomerulopathy. Clin J Am Soc Nephrol. 2012;7(5):735-41. https://doi.org/1 0.2215/CJN.07270711.

38. Siener R, Glatz S, Nicolay C, Hesse A. The role of overweight and obesity in calcium oxalate stone formation. Obes Res. 2004;12(1):106-13. https://doi. org/10.1038/oby.2004.14.

39. Chung HF, Long KZ, Hsu CC, al Mamun A, Jhang HR, Shin SJ, et al. Association of $n-3$ polyunsaturated fatty acids and inflammatory indicators with renal function decline in type 2 diabetes. Clin Nutr. 2015;34(2):229-34. https://doi.org/10.1016/j.clnu.2014.02.009.

40. Wing RR, et al. Cardiovascular effects of intensive lifestyle intervention in type 2 diabetes. N Engl J Med. 2013;369(2):145-54. https://doi.org/10.1056/ NEJMoa1212914

\section{Publisher's Note}

Springer Nature remains neutral with regard to jurisdictional claims in published maps and institutional affiliations.

Ready to submit your research? Choose BMC and benefit from:

- fast, convenient online submission

- thorough peer review by experienced researchers in your field

- rapid publication on acceptance

- support for research data, including large and complex data types

- gold Open Access which fosters wider collaboration and increased citations

- maximum visibility for your research: over $100 \mathrm{M}$ website views per year

At $\mathrm{BMC}$, research is always in progress.

Learn more biomedcentral.com/submissions 